\title{
Pengaruh jenis dan waktu aplikasi pupuk organik terhadap pertumbuhan dan hasil tanaman jagung manis (Zea mays L. Saccarata Strurt)
}

\author{
Effect of type and time of application of organic fertilizer on growth and yield of sweet corn \\ (Zea mays L. Saccarata Strurt)
}

Widyana Rahmatika ${ }^{1}$ dan Marista Anggraini ${ }^{1}$

${ }^{1}$ Agroteknologi, Fakultas Pertanian Uniska Kediri

*Email korespondensi: widyanarahmatika@gmail.com

Diterima: 29 Juni 2021 / Disetujui: 04 September 2021

\begin{abstract}
Sweet corn is a commodity that can be cultivated intensively because it is so popular that it opens up good market opportunities. The market demand for sweet corn which continues to increase and the high price of sweet corn are factors that can stimulate farmers to develop sweet corn farming (Hayati, 2006). The application of organic fertilizers in sweet corn cultivation can maintain the health and sustainability of the land, through the addition of organic fertilizers to agricultural land it can improve soil fertility because organic fertilizers can improve the physical, chemical and biological properties of the soil. This study aims to determine the interaction between types of organic fertilizers and the time of administration on the productivity of Sweet Corn (Zea mays L. Saccharata Sturt). This research took place in Manisrenggo Village, Manisrenggo District, Kediri City. When the research was started in September 2019 - November 2019. Soil types in Manisrenggo Village are sandy loam, pH 5.5 and elevation of $68 \mathrm{~m}$ above sea level. The research method used was a factorial design using a factorial randomized block design (RAKF) consisting of 2 factors, the first factor was 2 levels and the second factor was 3 levels and repeated four times. The results showed that there was an interaction due to the effect of the type of organic fertilizer and the time of administration on the productivity of Sweet Corn (Zea mays L. Saccharata Sturt) on the parameters of plant height, number of leaves (35, 45 dat), stem diameter (28,35,42 dat).
\end{abstract}

Keywords: organic fertilizer, type, time of aplication, sweet corn.

\section{ABSTRAK}

Jagung manis termasuk komoditi yang dapat diusahakan secara intensif karena banyak digemari sehingga terbuka peluang pasar yang baik. Kebutuhan pasar akan jagung manis yang terus meningkat dan harga jagung manis yang tinggi merupakan faktor yang dapat merangsang petani untuk mengembangkan usahatani jagung manis (Hayati, 2006). Aplikasi pupuk organik dalam budidaya jagung manis dapat menjaga kesehatan dan keberlanjutan lahan, melalui penambahan pupuk organik ke lahan pertanian dapat memperbaiki kesuburan tanah karena pupuk organik dapat memperbaiki sifat fisik, kimia dan biologi tanah. Penelitian ini bertujuan untuk mengetahui interaksi jenis pupuk organik dan saat pemberian terhadap produktivitas tanaman Jagung Manis (Zea mays L. Saccharata Sturt). Penelitian ini bertempat di Kelurahan Manisrenggo Kecamatan Manisrenggo Kota Kediri. Waktu penelitian di mulai pada bulan September 2019 - November 2019. Jenis tanah yang ada di Kelurahan Manisrenggo yaitu Lempung berpasir, pH 5,5 dan ketinggian tempat $68 \mathrm{~m}$ dpl. Metode Penelitian yang digunakan adalah rancangan faktorial dengan menggunakan Rancangan Acak Kelompok Faktorial (RAKF) terdiri dari 2 faktor, faktor pertama 2 level dan faktor yang kedua 3 level dan di ulang sebanyak empat kali. Hasil penelitian menunjukkan terdapat interaksi akibat pengaruh jenis pupuk organik dan saat pemberian terhadap produktivitas tanaman Jagung Manis (Zea mays L. Saccharata Sturt) pada parameter tinggi tanaman, jumlah daun (35, 45 hst), diameter batang (28,35,42 hst).

Kata kunci: jagung manis, jenis, pupuk organik, saat pemberian.

\section{PENDAHULUAN}

\section{Latar Belakang}

Jagung manis merupakan komoditi yang dapat diusahakan secara intensif, karena banyak digemari sehingga terbuka peluang pasar yang baik. Kebutuhan pasar yang terus meningkat dan harga jagung manis yang tinggi merupakan faktor yang dapat merangsang petani untuk mengembangkan usahatani jagung manis (Hayati N, 2006).

Terdapat beberapa cara yang dapat dilakukan untuk memproduksi tanaman, salah satunya dengan cara pemupukan. Aplikasi pupuk organik dalam budidaya jagung manis dapat menjaga kesehatan dan keberlanjutan lahan, melalui penambahan pupuk organik ke lahan pertanian dapat memperbaiki kesuburan tanah karena pupuk organik dapat memperbaiki sifat fisik, kimia dan biologi tanah. 
Pemanfaatan limbah pertanian merupakan salah satu cara yang dapat dilakukan untuk mencegah pencemaran lingkungan serta dapat dijadikan masukan bagi petani atau masyarakat yang memanfaatkan limbah untuk diolah menjadi bokasi, dimana proses pembuatan bokasi ini melalui fermentassi dengan memanfaatkan mikroorganisme. Selain pupuk bokasi, pupuk kascing juga merupakan salah satu pupuk organik yang baik untuk meningkatkan kesuburan tanah. Pembuatan pupuk kascing dengan simulator cacing tanah (Lumbricus rubellus). Kotoran cacing (kascing) merupakan pupuk organik yang sangat baik bagi tumbuhan, karena mudah diserap dan mengandung unsur hara yang di butuhkan oleh tanaman.

\section{BAHAN DAN METODE}

\section{Waktu dan Tempat Penelitian}

Penelitian ini bertempat di Kelurahan Manisrenggo Kecamatan Manisrenggo Kota Kediri . Waktu penelitian di mulai pada bulan September 2019 - November 2019. Jenis tanah yang ada di Kelurahan Manisrenggo yaitu Lempung berpasir, pH 5,5 dan ketinggian tempat $68 \mathrm{~m}$ dpl.

\section{Alat dan Bahan Penelitian}

Alat yang digunakan pada penelitian ini yaitu, traktor, cangkul, diesel, selang, ember, buku catatan, bolpoin, kamera, penggaris, karung, sabit, jangka sorong ,kertas label, Refaktometer dan timbangan. Bahan yang digunakan pada penelitian ini yaitu Jagung manis, pupuk organik (bokasi dan kascing), pupuk anorganik (NPK Mutiara).

\section{Metode Penelitian}

Metode Penelitian ini menggunakan rancangan faktorial dengan menggunakan Rancangan Acak Kelompok Faktorial (RAKF) terdiri dari 2 faktor, faktor pertama 2 level dan faktor yang kedua 3 level dan di ulang sebanyak empat kali.

Faktor 1: Perlakuan jenis pupuk organik ( $\mathrm{J})$ yang terdiri dari 2 level

J1: Pupuk Bokasi 10 ton/ha

J2: Pupuk Kascing 10 ton/ha

Faktor 2: perlakuan saat pemberian

S1: 1 minggu sebelum tanam
S2: 2 minggu sebelum tanam
S3: 3 minggu sebelum tanam

\section{HASIL DAN PEMBAHASAN}

\section{Pengaruh Perlakuan Terhadap Pertumbuhan Tanaman}

Penggunaan bokhasi dan kascing serta waktu aplikasi yang berbeda memberikan pengaruh yang berbeda terhadap pertumbuhan tanaman jagung. Rata-rata perlakuan terbaik terdapat pada perlakuan P1W2. Pemberian bokhasi menunjukkan pengaruh pada pertumbuhan yang lebih baik daripada pemberian kascing. Hal ini dapat terjadi karena perbedaan kandungan unsur hara pada keduanya. Kandungan $\mathrm{N}$ pada bokhasi sebesar $1.96 \%$ sedangkan kandungan $\mathrm{N}$ pada kascing sebesar $0.63 \%$. Unsur hara $\mathrm{N}$ merupakan komponen utama berbagai senyawa dalam tanaman seperti protein dan klorofil. Ketersediaan $\mathrm{N}$ yang baik, sintesis protein dan klorofil juga lebih baik sehingga laju fotosintesis juga akan lebih baik, klorofil sangat bermanfaat untuk menyerap cahaya untuk proses fotosintesis (Yulia AE, 2010). Waktu aplikasi bokhasi dua minggu sebelum tanam merupakan waktu yang paling efektif dalam menunjang pertumbuhan tanaman jagung manis. Besar kecilnya dampak yang diberikan kepada tanah akibat aplikasi bahan organik sangat dipengaruhi oleh macam dan tingkat kecepatan proses dekomposisi bahan organik tersebut. Kecepatan proses dekomposisi sangat dipengaruhi oleh tinggi rendahnya nilai $\mathrm{C} / \mathrm{N}$. Bahan organik dengan nilai rasio $\mathrm{C} / \mathrm{N}$ tinggi (> 15) menunjukkan dekomposisi belum lanjut atau baru mulai. (Kastono, 2005 dalam Suminarti NE, 2015).Sehingga, agar bahan organik yang diaplikasikan tersebut dapat memberikan manfaat untuk kesehatan tanah, maka diperlukan waktu aplikasi 2 minggu sebelum tanam.

Bokasi secara biologis dapat menekan pertumbuhan hama, penyakit dan meningkatkan aktifitas mikroorganisme dalam tanah serta secara kimia dapat menetralkan $\mathrm{pH}$ tanah. Dari segi biologi, pupuk bokasi membantu menghidupkan kembali mikroba-mikroba dalam tanah, mikroba sendiri berguna untuk memudahkan melakukan proses pembentukan bahan-bahan organik didalam tanah.. Bokasi dapat menyumbangkan unsur $\mathrm{N}, \mathrm{P}$, dan $\mathrm{K}$ ke dalam tanah, sehingga bisa meningkatkan ketersediaan unsur-unsur tersebut dalam tanah (Fitriyani Elsa A, et all 2020). Fungsi bahan organik secara kimia berfungsi dalam memberikan sumbangan hara melalui dekomposisi (Iswahyudi et. all., 2020).

Tabel 1. Rata-rata tinggi tanaman $(\mathrm{cm})$ pada perlakuan jenis pupuk organik dan saat pemberian pada berbagai umur pengamatan

\begin{tabular}{lccccc}
\hline Perlakuan & \multicolumn{5}{c}{ Umur Tanaman (hst) } \\
\cline { 2 - 6 } & 14 & 21 & 28 & 35 & 42 \\
\hline J1S1 & $24.84 \mathrm{~b}$ & $37.04 \mathrm{ab}$ & $55.67 \mathrm{ab}$ & $95.66 \mathrm{c}$ & $123.93 \mathrm{~b}$ \\
J1S2 & $23.35 \mathrm{a}$ & $35.47 \mathrm{a}$ & $58.26 \mathrm{~b}$ & $98.31 \mathrm{~d}$ & $126.10 \mathrm{~b}$ \\
J1S3 & $25.35 \mathrm{~b}$ & $37.51 \mathrm{~b}$ & $67.00 \mathrm{c}$ & $89.04 \mathrm{~b}$ & $109.56 \mathrm{a}$ \\
J2S1 & $25.15 \mathrm{~b}$ & $35.55 \mathrm{a}$ & $54.07 \mathrm{a}$ & $94.43 \mathrm{c}$ & $123.17 \mathrm{~b}$ \\
J2S2 & $25.23 \mathrm{~b}$ & $36.45 \mathrm{ab}$ & $65.48 \mathrm{c}$ & $86.79 \mathrm{ab}$ & $110.03 \mathrm{a}$ \\
J2S3 & $24.38 \mathrm{~b}$ & $35.83 \mathrm{a}$ & $65.23 \mathrm{c}$ & $85.74 \mathrm{a}$ & $109.87 \mathrm{a}$ \\
\hline
\end{tabular}

Keterangan: Angka-angka yang diikuti oleh huruf yang sama pada kolom dan perlakuan yang sama menunjukkan tidak berbeda nyata pada taraf 5\% (Uji DMRT) 
Tabel 2. Rata-rata jumlah daun (helai) pada perlakuan jenis pupuk organik dan saat pemberian pada umur 35 dan 42 hst

\begin{tabular}{lcc}
\hline Perlakuan & \multicolumn{2}{c}{ Umur Tanaman (hst) } \\
\cline { 2 - 3 } & 35 & 42 \\
\hline J1S1 & $9.13 \mathrm{~b}$ & $11.15 \mathrm{~b}$ \\
J1S2 & $9.60 \mathrm{~b}$ & $11.85 \mathrm{~b}$ \\
J1S3 & $7.53 \mathrm{a}$ & $8.80 \mathrm{a}$ \\
J2S1 & $9.18 \mathrm{~b}$ & $11.10 \mathrm{~b}$ \\
J2S2 & $7.45 \mathrm{a}$ & $8.70 \mathrm{a}$ \\
J2S3 & $7.15 \mathrm{a}$ & $8.85 \mathrm{a}$ \\
\hline
\end{tabular}

Keterangan : Angka-angka yang diikuti oleh huruf yang sama pada kolom dan perlakuan yang sama menunjukkan tidak berbeda nyata pada taraf 5\% (Uji DMRT)

Tabel 3. Rata-rata diameter batang $(\mathrm{cm})$ pada perlakuan jenis pupuk organik dan saat pemberian pada umur pengamatan 28,35 dan 42 hst

\begin{tabular}{llll}
\hline Perlakuan & \multicolumn{3}{c}{ Umur Tanaman (hst) } \\
\cline { 2 - 4 } & 28 & 35 & 42 \\
\hline J1S1 & $1.02 \mathrm{c}$ & $1.57 \mathrm{c}$ & $1.92 \mathrm{~b}$ \\
J1S2 & $1.10 \mathrm{~d}$ & $1.64 \mathrm{c}$ & $1.92 \mathrm{~b}$ \\
J1S3 & $0.87 \mathrm{ab}$ & $1.17 \mathrm{a}$ & $1.25 \mathrm{a}$ \\
J2S1 & $1.00 \mathrm{c}$ & $1.61 \mathrm{c}$ & $1.88 \mathrm{~b}$ \\
J2S2 & $0.85 \mathrm{a}$ & $1.07 \mathrm{a}$ & $1.24 \mathrm{a}$ \\
J2S3 & $0.93 \mathrm{~b}$ & $1.30 \mathrm{~b}$ & $1.81 \mathrm{~b}$ \\
\hline
\end{tabular}

Keterangan : Angka-angka yang diikuti oleh huruf yang sama pada kolom dan perlakuan yang sama menunjukkan tidak berbeda nyata pada taraf 5\% (Uji DMRT)

Tabel 4. Rata-rata brix pada perlakuan jenis pupuk organik dan saat pemberian pada saat panen

\begin{tabular}{lc}
\hline Perlakuan & Brix \\
\hline J1S1 & $12.53 \mathrm{~b}$ \\
J1S2 & $12.33 \mathrm{ab}$ \\
J1S3 & $12.18 \mathrm{a}$ \\
J2S1 & $12.65 \mathrm{~b}$ \\
J2S2 & $12.45 \mathrm{~b}$ \\
J2S3 & $12.70 \mathrm{~b}$ \\
\hline
\end{tabular}

Keterangan : Angka-angka yang diikuti oleh huruf yang sama pada kolom dan perlakuan yang sama menunjukkan tidak berbeda nyata pada taraf 5\% (Uji DMRT)

Tabel 5. Rata-rata berat tongkol (gram) pada perlakuan macam pupuk organik dengan interval waktu aplikasi pada waktu panen

\begin{tabular}{lc}
\hline Perlakuan & Berat (gram) \\
\hline J1 & $294.64 \mathrm{a}$ \\
J2 & $318.86 \mathrm{~b}$ \\
BNT 5\% & 9.31 \\
S1 & $217.72 \mathrm{c}$ \\
S2 & $189.73 \mathrm{a}$ \\
S3 & $206.06 \mathrm{~b}$ \\
BNT 5\% & 11.4 \\
\hline Keterangan : Angka-angka yang diikuti oleh huruf yang sama pada kolom dan perlakuan yang sama menunjukkan tidak berbeda nyata pada
\end{tabular}
taraf 5\% (Uji BNT)

Aplikasi bokasi ke dalam tanah dapat meningkatkan kandungan bahan organik dan unsur hara tanah. Jika semakin tinggi dosis pupuk bokasi yang diberikan, maka $\mathrm{N}$ yang terkandung di dalam pupuk bokasi juga semakin banyak yang diterima oleh tanah. Nitrogen merupakan unsur hara yang sangat penting karena merupakan unsur hara yang paling banyak dibutuhkan untuk pertumbuhan tanaman. Peran Nitrogen sebagai penyusun asam asam amino, protein komponen pigmen klorofil yang penting dalam proses fotosintesis. Sebaliknya jika kekurangan N menyebabkan pertumbuhan dan perkembangan tanaman terganggu dan hasil menurun yang disebabkan oleh terganggunya pembentukan klorofil yang sangat penting untuk proses fotosintesis (Mulyanti Siska Sari et.al, 2015).

Dekomposisi bahan organik ditentukan oleh saat pemberian bahan organik. Bahan organik yang telah 
terdekomposisi harus segera diberikan ke tanaman pada waktu yang tepat agar unsur hara yang dikandungnya dapat dimanfaatkan secara efektif serta menghindari terjadinya kehilangan akibat pencucian air hujan (Hayati N, 2006). Kesesuain waktu antara pemberian dan saat tanaman membutuhkan unsur hara ini dikenal dengan istilah sinkronisasi, apabila penyediaan unsur hara tidak sesuai maka akan terjadi defisiensi unsur hara ataupun kelebihan walaupun jumlah total penyediaan sama dengan jumlah total kebutuhan. Tidak terjadinya sinkronisasi atau asinkronisasi disebabkan oleh dua hal, yakni jika penyediaan lebih lambat ubtuk kebutuhan dan jika penyediaan terjadi lebih awal disbanding kebutuhan Tingkat sinkronisasi ditentukan oleh kecepatan dekomposisi dan mineralisasi dari bahan organik (Handayanto Eko et. all, 2017).

\section{Pengaruh Perlakuan Terhadap Hasil Tanaman}

Komponen hasil akhir suatu tanaman merupakan fungsi dari pertumbuhan, dan pertumbuhan tanaman sangat dikendalikan oleh 3 faktor, yaitu : (1) faktor lingkungan, (2) faktor genetik, dan (3) faktor manajemen. Apabila diketahui faktor genetik bukan merupakan kendala dalam budidaya tanaman, maka pertumbuhan dan hasil tanaman sangat dipengaruhi oleh faktor lingkungan dan manajemen. Lingkungan dan tanaman merupakan kesatuan yang tidak dapat dipisahkan. Oleh karena itu, agar tanaman dapat tumbuh berkembang dengan baik dan dapat menyelesaikan siklus hidupnya secara utuh, maka diperlukan lingkungan yang optimum. Adapun faktor lingkungan dibedakan menjadi lingkungan atas tanah dan lingkungan bawah tanah yang mencakup tanah, air dan unsur hara (Sitompul dan Guritno, 1995). Tanah sebagai tempat tegaknya tanaman, selain sebagai penyedia air dan nutrisi bagi tanaman. Oleh karena itu, agar tanah dapat mendukung proses perkembangan tanaman, maka kondisi tanah yang baik secara fisik, kimia dan biologi sangat diperlukan (Andayani dan Sarido, 2013) dalam (Suminarti NE, 2015). Pada parameter berat tongkol tidak terjadi interaksi yang nyata akibat pengaruh perlakuan, hal ini terjadi karena tiap-tiap faktor perlakuan tersebut, tidak saling memberi pengaruh.

Berdasarkan hasil uji lanjut BNT, parameter berat tongkol paling tinggi terdapat pada perlakuan J1. Pemberian bokasi memberikan pengaruh nyata pada parameter tinggi tanaman, jumlah daun, diameter batang dan produksi tanaman jagung manis. Pemberian bokasi ke dalam tanah dapat memperbaiki tata udara tanah dan air tanah, dengan demikian perakaran tanaman akan berkembang dengan baik dan akar dapat menyerap unsur hara lebih banyak, terutama unsur hara $\mathrm{N}$ yang akan meningkatkan produktivitas tanaman, mengingat kandungan unsur hara tertinggi dalam bokhasi adalah unsur hara Nitrogen. Unsur Nitrogen merupakan unsur hara yang sangat penting karena merupakan unsur yang paling banyak dibutuhkan untuk pertumbuhan tanaman. Asam-asam amino, protein komponen pigmen klorofil yang penting dalam proses fotosintesis disusun oleh unsur hara Nitrogen sebagai penyusun Sebaliknya jika kekurangan N menyebabkan pertumbuhan dan perkembangan tanaman terganggu dan hasil menurun yang disebabkan oleh terganggunya pembentukan klorofil yang sangat penting untuk proses fotosintesis (Mulyanti SS, 2015). Pemupukan Nitrogen dapat meningkatkan aktifitas akar sehingga merangsang pembelahan sel-sel meristematik dan memacu pertumbuhan tanaman. Ditambahkan pula oleh hasil penelitian Hayati N, 2006 yang menyatakan bahwa pemberian pupuk organik berpengaruh nyata terhadap berat tongkol jagung manis, sedangkan waktu aplikasi bokasi limbah kulit buah kakao dan interaksinya tidak berpengaruh nyata. Adrianton dan Wahyudi (2005), dalam (Hayati N, 2006).

\section{KESIMPULAN}

Terjadi interaksi akibat pengaruh perlakuan jenis pupuk organik dan saat pemberian terhadap pertumbuhan dan produksi tanaman jagung manis (Zea mays L. Saccharata Sturt) pada parameter tinggi tanaman, jumlah daun $(35,45$ hst), diameter batang $(28,35,42 \mathrm{hst})$. Terjadi pengaruh akibat perlakuan jenis pupuk organik pada parameter berat tongkol tanpa klobot. Terjadi pengaruh akibat perlakuan interval waktu aplikasi pupuk organik pada parameter berat tongkol tanpa klobot

\section{DAFTAR PUSTAKA}

Fitriyani E. A., Zainal A. (2020). Pengaruh Pupuk Bokashi Terhadap Pertumbuhan Mentimun (Cucumis sativus L.) di Desa Sukawening, Kabupaten Bogor, Jawa Barat. Jurnal Pusat Inovasi Masyarakat, 2(5), 881886.

Handayanto E., Muddarisna N., Fiqri A. (2017). Pengelolaan Kesuburan Tanah. UB Press. Universitas Brawijaya Malang

Hayati N. (2006). Pertumbuhan Dan Hasil Jagung Manis Pada Berbagai Waktu Aplikasi Bokashi Limbah Kulit Buah Kakao dan Pupuk Anorganik. J. Agroland, 13 (3), 256-259.

Iswahyudi, Izah A., Nisak A. (2020). Studi Penggunaan Pupuk Bokashi (Kotoran Sapi) Terhadap Tanaman Padi, Jagung \& Sorgum. Jurnal Pertanian Cemara (Cendekiawan Madura), 17(1), 14 - 20.

Mulyanti SS, Made U., Wahyudi I. (2015). Pengaruh Pemberian Berbagai Jenis Bokashi Terhadap Pertumbuhan Dan Hasil Tanaman Jagung Manis (Zea Mays Saccarata). Jurnal Agrotekbis, 3(5), 592 - 601.

Sitompul SM, Guritno, B. (1995). Analisis Pertumbuhan Tanaman. Gadjah Mada University Press. Yogyakarta

Suminarti, N.E. (2015). Pengaruh Macam dan Waktu Aplikasi Bahan Organik Pada Tanaman Ubi Jalar (Ipomoea Batatas L.) Var. Kawi. Jurnal Agro, 2(1), 15-28.

Yulia, A.E. (2010). Aplikasi Pupuk Organik pada Tanaman Caisim Untuk Dua Kali Penanaman. Jurnal Teknobiologi, 1(2), 19-26. 